Altai State University

Rcta 3iwlogica Sibirica

Journal of Biology

Founded in 2015

\title{
The bees of the tribe Anthophorini Dahlbom, 1835 (Hymenoptera: Apoidea: Apidae) of Nakhchichivan Autonomous Republic of the Azerbaijan
}

\author{
M.M. Maharramov', Kh.A. Aliyev², A.B. Bayramov ${ }^{1}$ \\ ${ }^{1}$ Institute of Bioresources of Nakhchivan Branch of National Academy of Sciences of Azerbaijan, Babak str., 10, \\ Nakhchivan AZ 7000 Azerbaijan.E-mail: mahir_maherramov@mail.ru \\ ${ }^{2}$ Institute of Zoology of National Academy of Sciences of Azerbaijan, passage 1128, district 504, Baku AZ 1073 \\ Azerbaijan. E-mail: khalidaliyev@mail.ru
}

\begin{abstract}
In the entomofauna of the Nakhchivan Autonomous Republic, 37 species of true bees belonging to 3 genera of the tribe Anthophorini, found at different times within the area of the autonomous republic is presented. The genus Amegilla is represented 3 subgenus (Amegilla, Micramegilla, Zebramegilla) and 7 species, the genus Anthophora 7 subgenus (Anthophora, Caranthophora, Dasymegilla, Heliophila, Lophanthophora, Melea, Paramegilla, Petalosternon, Pyganthophora) and 28 species, and the genus Hapropoda 2 species. Anthophora bimaculata (Panzer, 1798), A. richaensis Alfken, 1938, A. gracilipes (Morawitz, 1872), A. harmalae Morawitz, 1878, A. meridionalis Fedtschenko, 1875 and A. podagra Lepeletier, 1841 are newly recorded from Nakhchivan AR. The habitat landscapes of those species, biotopes and their feeding sources, entomophilous plants, are identified. Species of tribe Anthophorini feed on flowers of plant species of 19 families of the flora of the autonomous republic. A great preference is given to the flowers of the plants of the families Asteraceae, Fabaceae and Lamiaceae.
\end{abstract}

Key words: Nakhchivan, landscapes, Amegilla, Anthophora, Habropoda.

\section{Пчелы трибы Anthophorini Dahlbom, 1835 (Hymenoptera: Apoidea: Apidae) Нахичеванской Автономной Республики Азербайджана}

\author{
М.М. Магеррамов ${ }^{1}$, Х.А. Алиев ${ }^{2}$, А.Б. Байрамов ${ }^{1}$ \\ ${ }^{1}$ Институт Биоресурсов Нахичеванского отделения НАН Азербайджана, ул. Бабек, 10, \\ Нахичевань AZ 7000 Азербайджан \\ ${ }^{2}$ Институт Зоологии НАН Азербайджана, проезд 1128, квартал 504, Баку AZ 1073 Азербайджан
}

В энтомофауне Нахичеванской Автономной Республики выявлено 37 видов из 3 родов пчел трибы Anthophorini, найденных в разное время в пределах территории автономной республики. Род Amegilla представлен 3 подродами (Amegilla, Micramegilla, Zebramegilla) и 7 видами, род Anthophora 7 подродами (Anthophora, Caranthophora, Dasymegilla, Heliophila, Lophanthophora, Melea, Paramegilla, Petalosternon, Pyganthophora) и 28 видами, а род Нарropoda 2 видами. Anthophora bimaculata (Panzer, 1798), A. richaensis Alfken, 1938, A. gracilipes (Morawitz, 1872), A. harmalae Morawitz, 1878, A. meridionalis Fedtschenko, 1875 и A. podagra Lepeletier, 1841 впервые указаны для фауны Нахичеванской АР. Установлены обитаемые видами ландшафты, биотопы и источники их питанияэнтомофильные растения. Виды трибы Anthophorini питаются на цветках видов растений 19 семейств флоры 
автономной республики. Большое предпочтение они дают цветкам растений семейств Asteraceae, Fabaceae и Lamiaceae.

Key words: Нахичевань, ландшафты, Amegilla, Anthophora, Habropoda.

\section{Введение}

В мире насчитывается свыше 690 видов, принадлежащих 7 родам трибы Anthophorini (Michener, 2007). В первом томе каталога Hymenoptera России указано 52 вида 3 родов трибы для данной территории (Antropov et al., 2017).

На Кавказском регионе и в том числе в Азербайджане во второй половине XIX века О.Радошковским и Ф.Моравицем впервые проведено научное описание видов Anthophora albomaculata Radoszkowsky, 1874; Anthophora carbonaria Morawitz, 1876; Anthophora croceipes Morawitz, 1876; Anthophora ruficornis Morawitz, 1878 этой трибы (Radoszkowsky, 1873; Morawitz, 1876, 1877). В современных классификациях эти виды проведены в синонимы.

При исследовании пчелиных Южного Кавказа автором (Skhirtladze, 1981) зарегистрировано 27 видов трибы. Приведены сведения о 23 видах пчелиных рода Anthophora данной трибы для Азербайджана (Aliyev, Maharramov, 2007).

\section{Материал и методы}

Исследовательская работа выполнена на основе анализа материалов, собранных авторами в разные годы и коллекционных сборов Института Зоологии НАН Азербайджана. Растения определены главным научным сотрудником Института Биоресурсов Нахичеванского отделения НАН Азербайджана, д.б.н., профессором А.Ш. Ибрагимовым. Таксономия видов Anthophorini дана по (Brooks, 1988; Kuhlmann et al., 2017). Oбщеe распространение дано по (Ascher, Pickering, 2017; Kuhlmann et al., 2017).

Виды, впервые указаные для фауны Нахичеванской АР, отмечены звездочкой.

\section{Результаты и обсуждение}

В результате собственных исследований в энтомофауне региона обнаружено 37 видов из 3 родов. Аннотированный список видов расположен в алфавитном порядке.

Семейство: Apidae Latreille, 1802

Подсемейство: Apinae Latreille, 1802

триба: Anthophorini Dahlbom, 1835

Род: Amegilla Friese, 1897

Подрод: Amegilla Friese, 1897

Amegilla (Amegilla) garrula (Rossi, 1790)

Материал: Ордубад, 26.VIII.1996, 1, С. Гаджиева.

Распространение: Южная Европа, Кавказ, Малая и Средняя Азия.

Экология: Найден в нижнегорном полупустынном ландшафте. Обитает на сухих склонах и пустынных лугах. В горы поднимается до 1300 м.

трофические связи: Astragalus cicer L., Medicago caucasica Vassilcz. (Fabaceae), Eryngium campestre L. (Apiaceae). Amegilla (Amegilla) ochroleuca (Perez, 1879)

Материал: Ордубад, Билав, 14.VI.1980, 2qо, Х. Алиев.

Распространение: Южная Европа, Северная Африка, Малая Азия, Закавказья.

Экология: Найден в нижнегорном полупустынном ландшафте. Обитает на сухих склонах, пустых территориях и поймах рек. В горы поднимается до 1300 м.

трофические связи: Salvia spinosa L. (Lamiaceae), Anthemis altissima (L.) J.Gay (Asteraceae), Lotus tenuis Waldst. et Kit. ex Willd., Melilotus neapolitanus Ten. (Fabaceae).

Amegilla (Amegilla) quadrifasciata (Villers, 1789)

Материал: Малый Кавказ, Биченек, 13.VIII.1978, 1\%, Х. Алиев; Бабек, Шыхмахмуд, 12.VI.2012, 1\%; Бабек, Сираб, 25.VIII.2016, 1 ; Нахичевань, 19.IX.2016, 1 ; Бабек, Шыхмахмуд, 19.ІХ.2016, 1 , М. Магеррамов.

Распространение: Южная Палеарктика.

Экология: Найден в низменном и нижнегорном полупустынном, среднегорном нагорно-ксерофитно-лугокустарниковом ландшафтах. Обитает в тугайных лесах, а также в садах, средних и низких горных степях и бахчах. В горы поднимается до 2000 м.

Трофические связи: Lotus corniculatus L., Melilotus albus Medik., Ononis arvensis L. (Fabaceae), Sisymbrium altissimum L. (Brassicaceae), Salvia sclarea L., Nepeta cataria L. (Lamiaceae).

Подрод: Micramegilla Brooks, 1988

Amegilla (Micramegilla) nigricornis Morawitz, 1873 
Maharramov, M.M. et al. The bees of the tribe Anthophorini.... Acta Biologica Sibirica, 2018, 4(2), 17-24

Материал: Джульфа, Гулистан, 950 м., 25.V.2006, 1 ; Джульфа, Нагаджир, 1300 m., Peganum harmala, 1.VI.2006, 1, М. Магеррамов.

Распространение: Северная Африка, Закавказья, Средняя и Центральная Азия, Россия, Китай, Монголия.

Экология: Найден в низменном и нижнегорном полупустынном ландшафтах. Обитает в садах, бахчах и на поймах рек. Собран на Peganum harmala. В горы поднимается до 1300 м.

Трофические связи: Alhagi pseudalhagi (M.Bieb.) Fisch., Lathyrus pratensis L. (Fabaceae), Peganum harmala L. (Nitrariaceae).

Amegilla (Micramegilla) velocissima (Fedtschenko, 1875)

Материал: Нахичевань, Бузгов, 10.VIII.1978, 1\%; Ордубад, Билав, 14-15.VI.1980, 19, Х. Алиев; Ордубад, 16.VIII.1996, 2oㅇ; 21.VIII.1996, 5ㅇ; 26.VIII.1996, 4우, С. Гаджиева; Джульфа, Башкенд, 30.VI.2005, 1; Гёйнюк, 21.VII.2005, 1क; Шахбуз, Кечили, 31.VII.2005, 1\%; Нахичевань, 25.VIII.2007, 2oq; Шахбуз, Кюлюс, 14.VI.2009, 1 , М. Магеррамов.

Распространение: Южная Палеарктика.

Экология: Найден в низменном и нижнегорном полупустынном, среднегорном нагорно-ксерофитно-лугокустарниковом ландшафтах. Обитает в горных степях и пустынях, зарослях по берегам рек, агроценозах и бахчах. В горы поднимается до 2000 м.

Трофические связи: Eryngium campestre L. (Apiaceae), Zygophyllum fabago L. (Zygophyllaceae), Linum tenuifolium L. (Linaceae), Lotus corniculatus L., Lotus sp (Fabaceae).

Подрод: Zebramegilla Brooks, 1988

Amegilla (Zebramegilla) albigena (Lepeletier, 1841)

Материал: Ордубад, Билав, 13-14.VI.1980, 3ㅇ, Х. Алиев; Джульфа, Башкенд, 30.VI.2005, 1 ; Джульфа, гёйнюк,

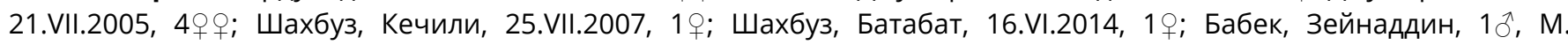
Магеррамов.

Распространение: Южная Палеарктика.

Экология: Найден в нижнегорном полупустынном и среднегорном нагорно-ксерофитно-луго-кустарниковом ландшафтах. Обитает в степях, посевах люцерны и садах. В горы поднимается до 2000 м.

трофические связи: Teucrium orientale L., Teucrium polium L. (Lamiaceae), Bryonia alba L., Bryonia dioica Jacq. (Cucurbitaceae), Echium vulgare L. (Boraginaceae).

Amegilla (Zebramegilla) salviae (Morawitz, 1876)

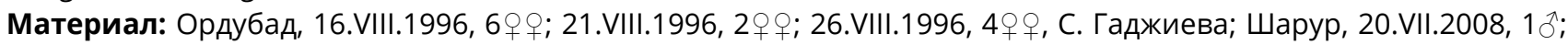
Нахичевань, 22.VI.2015, 1ㅇ, М. Магеррамов.

Распространение: Южная Палеарктика.

Экология: Найден в низменном и нижнегорном полупустынном ландшафтах. Обитает в садах и на окрестных сухих склонах. В горы поднимается до 1300 м.

Трофические связи: Centaurea behen L. (Asteraceae), Lathyrus chloranthus Boiss. (Fabaceae), Zygophyllum fabago L. (Zygophyllaceae).

Род: Anthophora Latreille, 1803

Подрод: Anthophora Latreille, 1803

Anthophora (Anthophora) crinipes Smith, 1854

Материал: Ордубад, 26.V.1980, 4우 10ิ, Х. Алиев; Шарур, Багырсагдара, 1350 m., 13.IV.2006, 5qq, М. Магеррамов.

Распространение: Южная и Средняя Европа, Малая Азия, Кавказ.

Экология: Найден в нижнегорном полупустынном и среднегорном нагорно-ксерофитном ландшафтах. Обитает на горных степях, сухих, каменистых склонах и в садах. В горы поднимается до 1400 м.

Трофические связи: Prunus microcarpa (С.A.Mey.) K.Koch (Rosaceae), Zygophyllum atriplicoides Fisch. et C.A.Mey. (Zygophyllaceae), Ranunculus repens L. (Ranunculaceae), Astragalus ordubadensis Grossh., Onobrychis cornuta (L.) Desv. (Fabaceae), Elaeagnus orientalis L. (Elaeagnaceae).

Anthophora (Anthophora) fulvitarsis Brulle, 1832

Материал: Ордубад, Агдара, 2200 m., 15.VI.1980, 19; Ордубад, Гапыджыг, 16.VI.1980, 19, Х. Алиев; Шахбуз, Кюлюс, 14.VI.2009, 1 ; ; Джульфа, Асабу-Кахф, 18.V.2016, 2 ㅇ; Бабек, Сираб, 1.VI.2016, 2우, М. Магеррамов.

Распространение: Южная Палеарктика.

Экология: Найден в нижнегорном полупустынном, среднегорном нагорно-ксерофитном, высокогорном нагорно-луговом и луго-степном, субальпийском луговом ландшафтах. Обитает на горных степях и субалпийских лугах. В горы поднимается до 2700 м.

Трофические связи: Trifolium pratense L. (Fabaceae), Thymus nummularius M.Bieb., Salvia spinosa L., Salvia virgata Jacq. (Lamiaceae), Malva neglecta Wallr., Althaea officinalis L. (Malvaceae).

Anthophora (Anthophora) plumipes (Pallas, 1772)

Материал: Ордубад, 26.V.1980, 1 , Х. Алиев

Распространение: Голарктика. 
Экология: Найден в нижнегорном полупустынном ландшафте. Обитает в садах, парках и на сухих склонах. Полилектический. В основном предпочитает розоцветные. Гнездо строит на глинистых стенах, оврагах и склонах. В горы поднимается до 1200 м.

Трофические связи: Prunus incana (Pall.) Steven, Prunus avium (L.) L., Pyrus salicifolia Pall. (Rosaceae).

Anthophora (Anthophora) uljanini Fedtschenko, 1875

Материал: Ордубад, 26.V.1980, 1, 10․, Х. Алиев.

Распространение: Кавказ, Средняя Азия, Китай.

Экология: Найден в нижнегорном полупустынном ландшафте. Обитает в поливных садах и на окрестных сухих склонах. В основном предпочитает бобовые. В горы поднимается до 1300 м.

трофические связи: Astragalus persepolitanus Boiss., Astragalus ordubadensis Grossh. (Fabaceae), Stachys pubescens Ten. (Lamiaceae), Carduus nervosus K.Koch (Asteraceae).

Подрод: Caranthophora Brooks, 1988

Anthophora (Caranthophora) dufourii Lepeletier, 1841

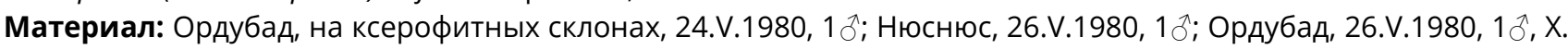
Алиев.

Распространение: Южная Европа, Малая Азия, Кавказ.

Экология: Найден в нижнегорном полупустынном и среднегорном нагорно-ксерофитном ландшафтах. Обитает на ксерофитных склонах и в садах. В горы поднимается до 1500 м.

трофические связи: Astragalus aduncus Willd., Astragalus ordubadensis Grossh. (Fabaceae), Achillea filipendulina Lam., Achillea tenuifolia Lam. (Asteraceae), Salvia sclarea L., Salvia viridis L., Thymus nummularius M.Bieb. (Lamiaceae).

Anthophora (Caranthophora) pubescens (Fabricius, 1781)

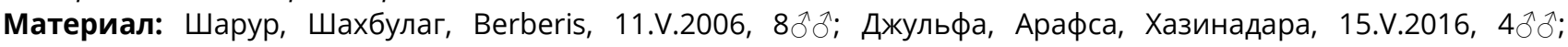
Джульфа, Асабу-Кахф, 18.V.2016, 1; Бабек, Сираб, 1.VI.2016, 1, М. Магеррамов.

Распространение: Южная и Средняя Европа, Северняя Африка, Израиль, Кавказ, Россия, Китай.

Экология: Найден в нижнегорном полупустынном и среднегорном нагорно-ксерофитно-луго-кустарниковом ландшафтах. Обитает на пойменных склонах рек. В горы поднимается до 1900 м.

трофические связи: Astragalus tribuloides Delile., Trifolium pratense L. (Fabaceae), Berberis vulgaris L. (Berberidaceae).

Подрод: Dasymegilla Brooks, 1988

Anthophora (Dasymegilla) quadrimaculata (Panzer, 1798)

Материал: Шахбуз, Кечили, 1800 м., 10.VI.2007, 1क; Джульфа, Башкенд, 6.VII.2007, 19; Бабек, Сираб, 6.V.2015,

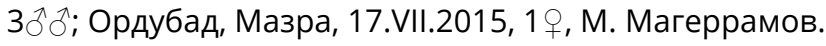

Распространение: Европа, Турция, Кавказ, Россия, Таджикистан, Казахстан, Китай.

Экология: Найден в среднегорном нагорно-ксерофитном, нагорно-ксерофитно-луго-кустарниковом ландшафтах. Обитает в садах и на ксерофитных склонах. В горы поднимается до 2000 м.

трофические связи: Carduus seminudus M.Bieb., Centaurea solstitialis L. (Asteraceae), Euphorbia grossheimii (Prokh.) Prokh. (Euphorbiaceae).

Подрод: Heliophila Klug, 1807

Anthophora (Heliophila) bimaculata (Panzer, 1798)*

Материал: Шахбуз, Кечили, 10.VI.2006, 1ㅇ, 10․ М. Магеррамов.

Распространение: Европа, Северная Африка, Малая Азия, Кавказ, Иран, Узбекистан, Таджикистан, Казахстан, Афганистан, Китай.

Экология: Найден в среднегорном нагорно-ксерофитно-луго-кустарниковом ландшафте. Обитает на ксерофитных склонах, каменистых и щебенистых участках. В горы поднимается до 2100 м.

Трофические связи: Melilotus albus Medik., Melilotus officinalis (L.) Pall., Onobrychis atropatana Boiss (Fabaceae).

Anthophora (Heliophila) richaensis Alfken, 1938*

Материал: Нахичеван, Бузгов, 10.VIII.1978, 1 ¿ै, Х.Алиев.

Распространение: Малая Азия, Закавказья.

Экология: Найден в нижнегорном полупустынном ландшафте. Обитает на горных степях и опустыненных лугах. В горы поднимается до 1400 м.

Трофические связи: Eryngium campestre L., Prangos uloptera DC. (Apiaceae).

Подрод: Lophanthophora Brooks, 1988

Anthophora (Lophanthophora) agama Radoszkowski, 1869

Материал: Ордубад, 26.V.1980, 1ㅇ, Х. Алиев; Джульфа, Башкенд, 22.V.2016, 1 \% , М. Магеррамов.

Распространение: Южная Европа, Кавказ, Малая и Средняя Азия, Китай.

Экология: Найден в нижнегорном полупустынном, среднегорном нагорно-ксерофитном ландшафтах. Обитает в садах и их окрестностях. В горы поднимается до 2000 м.

трофические связи: Astragalus persepolitanus Boiss. (Fabaceae), Mentha longifolia (L.) Huds., Salvia virgata Jacq. (Lamiaceae), Cirsium vulgare (Savi) Ten. (Asteraceae).

Anthophora (Lophanthophora) atricilla Eversmann, 1852 
Материал: Шахбуз, Кюлюс, 15.VI.2005, 1 \%, М. Магеррамов.

Распространение: Южная и Средняя Европа, Кавказ, Россия, Средняя Азия, Казахстан, Китай.

Экология: Найден в среднегорном нагорно-ксерофитном ландшафте. Обитает на сухих склонах. В горы поднимается до $1400 \mathrm{M}$.

Трофические связи: Astragalus persepolitanus Boiss. (Fabaceae), Thymus nummularius M.Bieb. (Lamiaceae).

Anthophora (Lophanthophora) biciliata Lepeletier, 1841

Материал: Ордубад, Гапыджыг, 16.VI.1980, 1 ภ̊, Х. Алиев.

Распространение: Южная Европа, Малая Азия, Кавказ.

Экология: Найден в высокогорном субальпийско-луговом ландшафте. Обитает в лугах и на травянистых склонах. В горы поднимается до 2700 м.

Трофические связи: Lamium purpureum L. (Lamiaceae).

Anthophora (Lophanthophora) robusta (Klug, 1845)

Материал: Нахичеван, 20.V.1926, 2우, М. Ахназаров.

Распространение: Южная Европа, Малая Азия, Кавказ, Россия, Сирия, Израиль, Иран, Туркменистан.

экология: Найден в низменном полупустынном ландшафте. Обитает в садах и на посевных участках. В горы поднимается до 1000 м.

Трофические связи: Lotus corniculatus L., Astragalus cicer L. (Fabaceae).

Подрод: Melea Sandhouse, 1943

Anthophora (Melea) plagiata (Illiger, 1806)

Материал: Ордубад, на ксерофитных склонах, 24.V.1980, 3qक, Х. Алиев; Шахбуз, Кечили, 26.VI.2004, 3qक; Ордубад, Билав, 2.VI.2016, 19, 10ิ, М. Магеррамов.

Распространение: Палеарктика.

Экология: Найден в нижнегорном полупустынном и среднегорном нагорно-ксерофитно-луго-кустарниковом ландшафтах. Обитает на ксерофитных склонах и горных лугах. Широко полилектический. В основном предпочитает бобовые. В горы поднимается до 2000 м.

Трофические связи: Euphorbia aserbajdzhanica Bordz. (Euphorbiaceae), Onobrychis heterophylla C.A.Mey., Trifolium alpestre L. (Fabaceae), Lamium tomentosum Willd., Salvia sclarea L. (Lamiaceae).

Подрод: Paramegilla Friese, 1897

Anthophora (Paramegilla) gracilipes (Morawitz, 1872)*

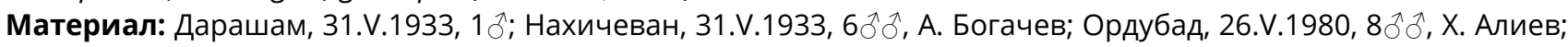

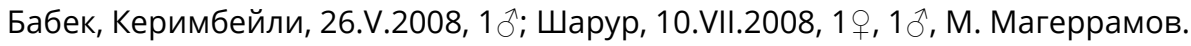

Распространение: Россия, Кавказ, Иран, Средняя Азия, Казахстан, Монголия, Китай.

Экология: Найден в низменном и нижнегорном полупустынном ландшафтах. Обитает на опустыненных степях и в садах. Встречается на ксерофитных каменистых оврагах, обочинах дорог и в глуши лесов на растении Zygophyllum fabago. В горы поднимается до 1200 м.

трофические связи: Ononis arvensis L., Lotus corniculatus L., Melilotus albus Medik. (Fabaceae), Zygophyllum fabago L (Zygophyllaceae).

Anthophora (Paramegilla) harmalae Morawitz, 1878*

Материал: Ордубад, Билав, 14.VI.1980, 1§, Х. Алиев; Бабек, Сираб, 1.VI.2016, 2q+9, М. Магеррамов.

Распространение: Малая Азия, Кавказ, Иран.

Экология: Найден в нижнегорном полупустынном ландшафте. Обитает в садах и на поймах рек. В горы поднимается до $1200 \mathrm{M}$.

Трофические связи: Zygophyllum atriplicoides Fisch. et C.A.Mey. (Zygophyllaceae).

Anthophora (Paramegilla) meridionalis Fedtschenko, 1875*

Материал: Шахбуз, Кечили, 1800 м, 3.VI.2007, 1\%; Джульфа, Башкенд, 6.VII.2007, 1+, М. Магеррамов.

Распространение: Кавказ, Средняя Азия.

Экология: Найден в среднегорном нагорно-ксерофитно-луго-кустарниковом ландшафте. Обитает в садах и на ксерофитных склонах. В горы поднимается до 1900 м.

Трофические связи: Vicia lutea L., Lotus corniculatus L. (Fabaceae), Lamium purpureum L., Salvia sclarea L., Thymus collinus M. Bieb. (Lamiaceae).

Anthophora (Paramegilla) podagra Lepeletier, 1841*

Материал: Джульфа, Арафса, Хазинадара, 19.V.2004, 1\%; Джульфа, Гал, 1100 m., 17.v.2007, 1\%; Кенгерли, Гарабаглар, 1200 m., 31.V.2007, 1, М. Магеррамов.

Распространение: Южная и Восточная Европа, Северная Африка, Малая Азия, Кавказ, Россия, Иран, Китай.

Экология: Найден в нижнегорном полупустынном, среднегорном нагорно-ксерофитном и нагорноксерофитно-луго-кустарниковом ландшафтах. На поймах рек и сухих склонах. В горы поднимается до 1900 м.

трофические связи: Nigella orientalis L. (Ranunculaceae), Carduus onopordioides Fisch. ex M.Bieb. (Asteraceae), Elaeagnus angustifolia L. (Elaeagnaceae), Verbascum speciosum Schrad. (Scrophulariaceae).

Подрод: Petalosternon Brooks, 1988

Anthophora (Petalosternon) crassipes Lepeletier, 1841 
Материал: Шахбуз, Кечили, 26.VI.2004, 4ㅇ;; Ордубад, Билав, 1100 м., Crataegus, 20.IV.2006, 1\%; Джульфа, Дарыдаг, 1200 м., 3.V.2007, 10; Джульфа, Шурут, 27.IV.2016, 10; Шарур, Пусян, 3.V.2016, 20ㅎ; Джульфа, Арафса,

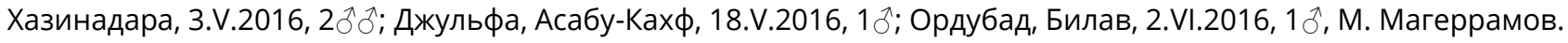

Распространение: Южная и Средняя Европа, Россия, Северная Африка, Турция, Израиль, Кавказ.

Экология: Найден в нижнегорном полупустынном и среднегорном нагорно-ксерофитно-луго-кустарниковом ландшафтах. Обитает на равнинах, ксерофитных склонах, поймах рек и в поливных садах. В горы поднимается до $2000 \mathrm{M}$.

Трофические связи: Crataegus orientalis Pall. ex M.Bieb. (Rosaceae), Cirsium rhizocephalum C.A.Mey. (Asteraceae), Stachys pubescens Ten., Salvia spinosa L. (Lamiaceae), Vicia lutea L., Melilotus officinalis (L.) Pall. (Fabaceae).

Anthophora (Petalosternon) radoszkowskyi Fedtschenko, 1875

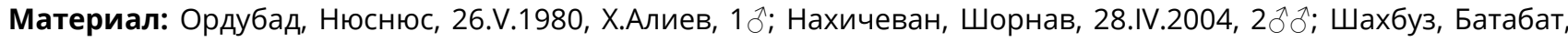

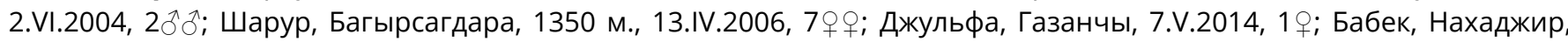
12.V.2016, 1 ; ; Джульфа, Асабу-Кахф, 18.V.2016, 2o+ , М. Магеррамов.

Распространение: Россия, Кавказ, Таджикистан, Кыргызстан, Казахстан.

Экология: Найден в низменном и нижнегорном полупустынном, среднегорном нагорно-ксерофитном и нагорно-ксерофитно-луго-кустарниковом ландшафтах. Обитает на ксерофитных склонах, лугах и в садах. Предпочтение дает видам Asteraceae. В горы поднимается до 2000 м.

трофические связи: Echium russicum J.F. Gmel., Onosma caucasicum Levin (Boraginaceae), Carduus nervosus K.Koch. (Asteraceae), Salvia viridis L. (Lamiaceae).

Подрод: Pyganthophora Brooks, 1988

Anthophora (Pyganthophora) aestivalis (Panzer, 1801)

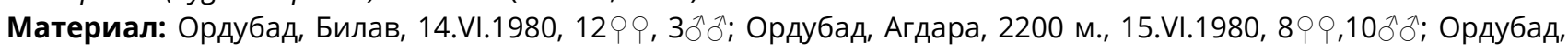

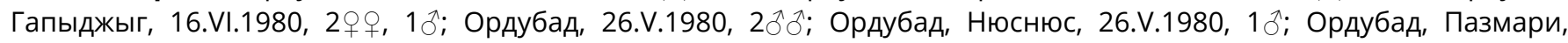

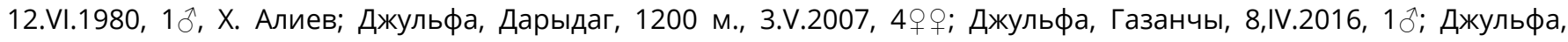
Башкенд, 22.V.2016, 19, М. Магеррамов.

Распространение: Южная и Средняя Европа, Россия, Кавказ, Турция, Израиль, Иордания, Иран.

Экология: Найден в нижнегорном полупустынном, среднегорном нагорно-ксерофитном, нагорноксерофитно-луго-кустарниковом и высокогорном субальпийско-луговом ландшафтах. Обитает на агроценозах, горных степях, травянистых склонах и субальпийских лугах. В горы поднимается до 2600 м.

Трофические связи: Zygophyllum fabago L. (Zygophyllaceae), Malva sylvestris L. (Malvaceae), Tamarix meyeri Boiss. (Tamaricaceae), Melilotus albus Medik. (Fabaceae), Gentiana gelida M. Bieb. (Gentianaceae), Nigella orientalis L. (Ranunculaceae), Stachys pubescens Ten (Lamiaceae).

Anthophora (Pyganthophora) altaica Radoszkowski, 1882

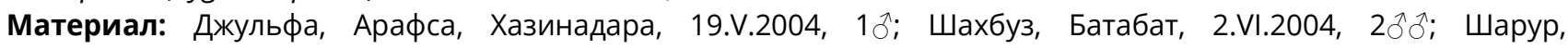
Багырсагдара, 1350 м., 13.IV.2006, 4우, М. Магеррамов.

Распространение: Россия, Украина, Кавказ, Средняя Азия, Монголия, Китай.

Экология: Найден в среднегорном нагорно-ксерофитном, нагорно-лесном и нагорно-ксерофитно-лугокустарниковом ландшафтах. Обитает в лесах и на горных лугах. В горы поднимается до 2000 м.

трофические связи: Prunus incana (Pall.) Steven, Malus orientalis Uglitzk. (Rosaceae), Verbascum gossypinum M.Bieb. (Scrophulariaceae), Linaria grandiflora Desf. (Plantaginaceae).

Anthophora (Pyganthophora) atriceps Perez, 1879

Материал: Шахбуз, Кюлюс, 15.VI.2005, 1क; Шахбуз, Батабат, 24.VI.2015, 2 qक , М. Магеррамов.

Распространение: Франция, Северная Африка, Малая Азия, Закавказья.

Экология: Найден в среднегорном нагорно-ксерофитном и нагорно-ксерофитно-луго-кустарниковом ландшафтах. Обитает на ксерофитных склонах. Встречается на цветках видов Fabaceae, Rhamnaceae и Lamiaceae. В горы поднимается до $2100 \mathrm{M}$.

Трофические связи: Astragalus tribuloides Delile (Fabaceae), Rhamnus pallasii Fisch. et C.A.Mey. (Rhamnaceae), Thymus collinus M. Bieb. (Lamiaceae).

Anthophora (Pyganthophora) erschowi Fedtschenko, 1875

Материал: Иличь, 18.V.1974, 1\%; Джульфа, 21.V.1974, 19, И. Схиртладзе; Бабек, Сираб, 1.VI.2016, 19, М. Магеррамов. Китай.

Распространение: Южная Европа, Северная Африка, Малая Азия, Россия, Кавказ, Казахстан, Афганистан,

Экология: Найден в низменном и нижнегорном полупустынном ландшафте. Обитает на степях и в ксерофильном редколесье. Предпочитает цветки видов Rosaceae и Fabaceae. В горы поднимается до 1200 м.

трофические связи: Malus orientalis Uglitzk., Prunus cerasus L., Pyrus communis L., Crataegus caucasica C.Koch (Rosaceae), Astragalus fabaceus M.Bieb., Melilotus albus Medik., Trifolium pratense L. (Fabaceae).

Anthophora (Pyganthophora) pedata Eversmann, 1852

Материал: Садарак, 1050 м, 6.IV.2006, 2qㅇ, М. Магеррамов.

Распространение: Болгария, Россия Турция, Азербайджан, Узбекистан, Казахстан, Китай. 
Maharramov, M.M. et al. The bees of the tribe Anthophorini.... Acta Biologica Sibirica, 2018, 4(2), 17-24

Экология: Найден в нижнегорном полупустынном ландшафте. Обитает в основном в садах и их окрестностях. В горы поднимается до 1200 м.

Трофические связи: Prunus incana (Pall.) Steven, Prunus microcarpa (C.A.Mey.) K.Koch. (Rosaceae).

Anthophora (Pyganthophora) retusa (Linnaeus, 1758)

Материал: Нахичеван, Бузгов, 10.VIII.1978, 4우, 2§ð, Х. Алиев.

Распространение: Палеарктика.

Экология: Найден в среднегорном нагорно-ксерофитном ландшафте. Обитает на ксерофитных склонах. Предпочитает цветки видов Fabaceae. В горы поднимается до 1500 м.

трофические связи: Melilotus officinalis (L.) Pall., Astragalus tribuloides Delile (Fabaceae), Linaria schelkownikowii Schischk. (Plantaginaceae).

Anthophora (Pyganthophora) testaceipes Morawitz, 1888

Материал: Шахбуз, Кюлюс, 15.VI.2005, 1 §; Ордубад, Мазра, 17.VII.2015, 1 , М. Магеррамов.

Распространение: Россия, Испания, Азербайджан, Узбекистан, Казахстан.

Экология: Найден в среднегорном нагорно-ксерофитном ландшафте. Обитает на сухих склонах и поймах рек. В горы поднимается до 1700 м.

трофические связи: Astragalus fragrans Willd., Ononis arvensis L., Onobrychis cyri Grossh., Medicago lupulina L (Fabaceae).

Anthophora (Pyganthophora) vernalis Morawitz, 1877

Материал: Шахбуз, Кечили, 26.VI.2004, 1\%; 10.VI.2007, 1\%, М. Магеррамов.

Распространение: Россия, Азербайджан, Израиль, Узбекистан, Казахстан.

Экология: Найден в среднегорном нагорно-ксерофитно-луго-кустарниковом ландшафте. Обитает на каменистых склонах и лугах. В горы поднимается до 1900 м.

Трофические связи: Astragalus conspicuus Boriss., Onobrychis cyri Grossh. (Fabaceae).

Род: Habropoda Smith, 1854

Habropoda tarsata (Spinola, 1838)

Материал: Ордубад, Агдара, 2200 m., 15.VI.1980, 2qo, Х. Алиев; Джульфа, Арафса, Хазинадара, 6.VI.2008, 1 , M. Магеррамов.

Распространение: Южная Европа, Малая Азия, Закавказья.

Экология: Найден в среднегорном нагорно-ксерофитно-луго-кустарниковом ландшафте. Обитает на каменисто-щебенистых склонах. В горы поднимается до 2200 м.

Трофические связи: Astragalus cicer L., Trifolium trichocephalum M.Bieb., Lathyrus pratensis L., Vicia angustifolia Reichard. (Fabaceae).

Habropoda zonatula Smith, 1854

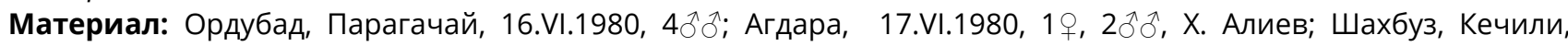
26.VI.2004, 1; Джульфа, Лекедаг, 22.VI.2016, 1, М. Магеррамов.

Распространение: Юго-Восточная Европа, Россия, Азербайджан, Турция, Сирия.

Экология: Найден в среднегорном нагорно-ксерофитно-луго-кустарниковом, высокогорном нагорнолуговом и луго-степном, субальпийско-луговом ландшафтах. Обитает на лугах и травянистых склонах. В горы поднимается до 2700 м.

Трофические связи: Nepeta racemosa Lam., Salvia ceratophylla L. (Lamiaceae), Echium vulgare L. (Boraginaceae), Lathyrus tuberosus L. (Fabaceae).

\section{Выводы}

В энтомофауне Нахичеванской Автономной Республики выявлено 37 видов из 3 родов пчел трибы Anthophorini, найденных в разное время в пределах территории автономной республики. Род Атеgilla представлен 3 подродами (Amegilla, Micramegilla, Zebramegilla) и 7 видами, род Anthophora 7 подродами (Anthophora, Caranthophora, Dasymegilla, Heliophila, Lophanthophora, Melea, Paramegilla, Petalosternon, Pyganthophora) и 28 видами, а род Hapropoda 2 видами. Anthophora bimaculata (Panzer, 1798), A. richaensis Alfken, 1938, A. gracilipes (Morawitz, 1872), A. harmalae Morawitz, 1878, A. meridionalis Fedtschenko, 1875 и A. podagra Lepeletier, 1841 впервые указаны для фауны Нахичеванской АР. Установлены обитаемые видами ландшафты, биотопы и источники их питанияэнтомофильные растения.

Виды трибы Anthophorini питаются на цветках видов растений 19 семейств флоры автономной республики. Большое предпочтение они дают цветкам растений семейств Asteraceae, Fabaceae и Lamiaceae.

\section{References}

Aliyev, Kh.A., Maharramov, M.M. (2007). On the studies of Apidae from the genus Anthophora Latreille, 1803 (Hymenoptera: Apoidea) in the Nakhchivan Autonomous Republic. Gornyye ekosistemy i ikh komponenty. Trudy mezhdunarodnoy konferentsii (13-18 avgusta), chast' 1. Moskva: Tovarishchestvo nauchnykh izdaniy KMK, 38-41 (in Russian). 
Ascher, J.S., Pickering, J. (2017). Discover Life bee species guide and world checklist (Hymenoptera: Apoidea: Anthophila). Available at: http://www.discoverlife.org/mp/20q?guide=Apoidea_species (accessed 29 Decembr 2017).

Brooks R.W. (1988). Systematics and Phylogeny of the Anthophorine Bees (Hymenoptera: Anthophoridae: Anthophorini). The University of Kansas Science Bulletin, 53 (9), 436-575.

Kuhlmann, M., Ascher, J.S., Dathe, H.H., Ebmer, A.W., Hartmann, P., Michez, D., Muller, A., Patiny, S., Pauly, A., Praz, C., Rasmont, P., Risch, S., Scheuchl, E., Schwarz, M., Terzo, M., Williams, P.H., Amiet, F., Baldock, D., Berg, O., Bogusch, P., Calabuig, I., Cederberg, B., Gogala, A., Gusenleitner, F., Josan, Z., Madsen, H.B., Nilsson, A., Odegaard, F., Ortiz-Sanchez, J., Paukkunen, J., Pawlikowski, T., Quaranta, M., Roberts, S.P.M., Saropataki, M., Schwenninger, H.-R., Smit, J., Soderman, G., Tomozei, B. (2017). Checklist of the Western Palaearctic Bees (Hymenoptera: Apoidea: Anthophila). Available at: http://westpalbees.myspecies.info (accessed 29 August 2017).

Michener, C.D. (2007). The Bees of the World. Baltimore: Johns Hopkins University Press.

Antropov, A.V., Astafurova, Yu.V., Belokobylskij, S.A., Byvaltsev, A.M., Danilov, Yu.N., Dubovikoff, D.A., Fadeev, K.I., Fateryga, A.V., Kurzenko, N.V., Lelej, A.S., Levchenko, T.V., Loktionov, V.M., Mokrousov, M.V., Nemkov, P.G., Proshchalykin, M.Yu., Rosa, P., Sidorov, D.A., Sundukov, Yu.N., Yusupov, Z.M., Zaytseva, L.A. (2017). Annotated catalogue of the Hymenoptera of Russia. Volume I. Symphyta and Apocrita: Aculeata. Saint Petersburg.

Morawitz, F. (1876). Zur Bienenfauna der Caucasusländer. Horae Societies Entomologicae Rossicae, 12 (1), 3-69.

Morawitz, F. (1877) Nachtrag zur Bienenfauna Caucasiens. Horae Societatis Entomologicae Rossicae, 14 (1), 3-112.

Radoszkowsky, O. (1873). Materiaux pour servir a une faune hymenopterologique de la Russie. Horae Societatis Entomologicae Rossicae, 10 (1), 190-195.

Skhirtladze, I.A. (1981). Pchelinye Zakavkaz'ya (Hymenoptera, Apoidea) Tbilisi: Metsniereba (in Russian).

\section{Citation:}

Maharramov, M.M., Aliyev, Kh.A., Bayramov, A.B. (2018). The bees of the tribe Anthophorini Dahlbom, 1835 (Hymenoptera: Apoidea: Apidae) of Nakhchichivan Autonomous Republic of the Azerbaijan. Acta Biologica Sibirica, 4 (2), 17-24.

Submitted: 18.02.2018. Accepted: 01.04.2018

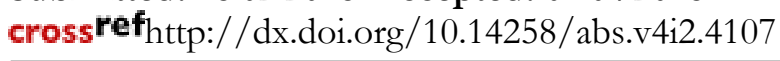

(C) 2018 by the authors. Submitted for possible open access publication under the terms and conditions of the Creative Commons Attribution (CC BY) license (http://creativecommons.org/licenses/by/4.0/). 